Article

\title{
Sustainability of Cluster Organizations as Open Innovation Intermediaries
}

\author{
Anna Maria Lis ${ }^{1, *(\mathbb{D}}$, Marita McPhillips ${ }^{1}(\mathbb{0})$ and Adrian Lis ${ }^{2}$ \\ 1 Faculty of Management and Economics, Gdańsk University of Technology, 80-233 Gdańsk, Poland; \\ Marita.Mcphillips@pg.edu.pl \\ 2 Department of Management, Collegium Civitas, 00-901 Warszawa, Poland; adrian.lis@civitas.edu.pl \\ * Correspondence: Anna.Lis@zie.pg.gda.pl; Tel.: +48-58-347-2803
}

Received: 20 November 2020; Accepted: 14 December 2020; Published: 16 December 2020

\begin{abstract}
The purpose of the paper is to identify the most important open innovation practices used by cluster organizations (COs). To reflect these practices, the paper uses the concept of the trajectory of relationship development in COs, applied in the Interizon cluster organization. Additionally, this paper introduces the potential sustainability-related implications of open innovation adoption in cluster organizations. An in-depth direct interview and secondary data analysis were the basic techniques used for data collection. The study demonstrates that cluster organizations can play the role of open innovation intermediaries, implementing a set of different open innovation practices, depending on the level of advancement of cluster cooperation. The use of these practices leads to the development of ever stronger relationships between cluster members, thus conditioning access to the increasingly valuable resources of information and knowledge which are most relevant for the future sustainability-pursuing context. The good effects of multidimensional cooperation in the studied cluster organization prompted the authors to formulate a recommendation for sustainable diversity in the $\mathrm{CO}$. The research goes beyond the state-of-the-art knowledge in the concept of industrial clusters by exposing a broader view on cooperation developed within cluster organizations. The study links the issue of clustering with the concept of open innovation, shedding new light on the processes of supporting knowledge and information flows in COs. Additionally, it contributes to developing a broader comprehension of the context dependencies of open innovation for potential sustainable innovation.
\end{abstract}

Keywords: cluster; cluster organization; open innovation; cooperation; sustainability

\section{Introduction}

Sustainable development, as a predominant issue in strategic policy documents at all levels, is forcing companies to seek efficient ways of using resources and explore collaborative models of innovation [1-3]. The literature points to the relevance of external partners for achieving sustainability performance [4] and open innovation seem to be predestined to be a practice that can lead to increased success [5]. Defined as "a distributed innovation process based on purposively managed knowledge flows across organizational and sectoral boundaries using pecuniary or nonpecuniary mechanisms" [6], open innovation is currently a broadly debated paradigm [7]. Researchers point to several game-changing benefits associated with the open innovation approach for companies. Open innovation, directly and indirectly, facilitates the improvement of a company's innovation outcomes by accessing new knowledge outside their bounds and reducing the costs of investment and sharing risks [8]. It is therefore not only economically effective, but it also increases the possibility of radical innovations, resulting in a higher potential for the company's development [9]. The open innovation approach emphasizes the assumption that the innovation process can be a cooperative 
attempt, even among competing firms. There is an increasing interest in its benefits, expenses, practices and mechanisms [10].

The open innovation approach embodies diverse inbound, outbound, and coupled processes for supporting knowledge flows across frontiers to generate innovations. Nonetheless, despite several years of research on this subject, the operationalization of the open innovation phenomena resulting from the diversity of implementation approaches remains a challenge for researchers [11,12]. Open innovation collaboration can involve different practices which vary greatly in terms of the process flow and the purpose to be achieved as a result of their use. Many researchers have undertaken the task of identifying examples of open innovation practices, which include innovation between companies, research and development cooperation, patenting and licensing, user innovation, open-source development, and crowdsourcing [13-17].

Clusters seem to be naturally predestined to foster open innovation [18]. Clusters are defined as agglomerations of cooperating companies, research institutions, governments, other organizations, and communities which are geographically localized [19]. Clusters represent, in practice, the quadruple helix model, with a highly developed network of collaborating partners [20]. The literature on innovations in clusters mentions activities favoring innovation cooperation between members, including support in the field of technology transfer, intersectoral innovation, innovation platforms, obtaining funds for innovative projects, social innovations and targeting the public sector [21]. The overlap is obvious but not always appropriately valued.

In the paper, we focus on the companies collaborating with cluster organizations (COs), whose objective is to ultimately achieve specific individual and collective goals. The paper aims to identify the most important practices used by COs as part of open innovation collaboration, on the basis of Interizon-The ICT Pomeranian Cluster (Interizon) - which is one of the most mature cluster organizations in Poland with well-developed open innovation practices.

Many studies, e.g., [22,23], indicate that innovation takes place more frequently in clusters, which support access to external partners. Successful clusters seem to have mastered the "practice of clustering"- a set of future-oriented practices executed collaboratively by regional partners and orchestrated to enhance the place-based structure $[24,25]$. The open innovation practices of clusters are viewed in this paper in the context of sustainability which addresses the companies' activities to implement sustainable principles across the industrial value chain. In theory, open innovation and networking processes in clusters meet this challenge. Open innovation emphasizes the ongoing relationship between the company and carefully selected cluster partners in the innovation process on a targeted basis. However, open innovation processes seem to be essentially separated from sustainability innovation processes in practice [26] and might benefit from supportive intermediation of a cluster.

The paper is structured as follows: At the beginning, we discuss the specific nature of cluster organizations, emphasizing their role as open innovation intermediaries. After the methodology section (which is the subsequent section), results and discussion are presented. Conclusions contain theoretical and practical implications, limitations and directions for further research.

\section{Theoretical Background}

The network approach pronounced by clusters underpins open innovation as much more than just flows of ideas in the initial stages of the innovation development process $[13,15,27]$. The open innovation model usually involves companies to orchestrate or actively take part in innovation ecosystems that bring together different sets of partners at subsequent stages of the innovation process. It seems that the key issue is the management of collaboration in these increasingly dynamic relationships. Researchers point to the potential role of open innovation intermediaries $[28,29]$.

Open innovation intermediaries are recognized, in a general sense, as innovation intermediaries s support the innovation process of companies and other actors of regional innovation systems. Howells [30] characterizes an innovation intermediary as "an organization that acts as an agent or broker in any aspect of the innovation process between two or more parties". Open innovation 
intermediaries support cooperation between diverse entities during different phases of the open innovation process, their main goal being knowledge and technology transfer as well as network development, which strengthens trust-building among network members [8,31].

Intermediation is particularly needed in the light of many barriers hindering the adoption of open innovation in firms, especially Small and medium-sized enterprises (SMEs). The lack of resources, organizational and technological capacities, trust barriers, and the Not-Invented-Here effect often mentioned in the literature seems to prevent companies from benefiting from the Open Innovation approach $[8,32]$. Open innovation intermediaries could provide much needed support for the interorganizational collaboration throughout the open innovation process.

Open innovation intermediaries should be viewed through their role in the multiarray open process which reaches out from linking actors for cooperation to arranging and intermediating partnerships and coupling a broad range of knowledge and capabilities [33,34]. The support of an open innovation intermediary can take the form of various activities determined by the challenges faced by a company in need, covering the whole open innovation process [35]. Nonetheless, the intermediary's capacity regarding particular industries is often undervalued. Howells [30] notes that because of their strong abilities to access information sources, open innovation intermediaries turn into experts in particular areas of knowledge. They often become important knowledge-generating entities, and then support the transfer of knowledge to actors in their network. Innovation intermediaries seem to be advancing new routines in settings where risk and uncertainty are high and where refined management practices have to be developed [36]. Clusters could potentially offer an environment of geographical proximity, trust, and effective management conducive to open innovation processes.

Clusters have been described in the literature as regional concentrations of large and small companies that develop creative products and services, along with specialized suppliers, service providers, universities, and associated institutions [37]. Ideally, they bring together a critical mass of skills and talent and are characterized by a high level of interaction among these entrepreneurs, researchers, and innovators.

Clusters are increasingly treated as orchestrators of an innovation ecosystem supporting the broadly understood processes of knowledge creation [38]. The concept of an ecosystem started as an ecological metaphor to explain the system-level complexities and can cover many types [39]. An innovation ecosystem in particular is defined as "interconnected organizations, organized around a focal firm or a platform, and incorporating both production and use side participants, and focusing on the development of new value through innovation" [40,41]. What distinguishes an innovation ecosystem is that universities or other research institutions often play a key role as the main source of research outputs [42].

Similar to clusters, development of the innovation ecosystem depends on the coordination of innovative activities of various partners [43]. The knowledge creation process in this context has two aspects-knowledge base and knowledge mechanisms [38]. Clusters not only have some features of a knowledge base, such as universities, research institutions or an access to highly qualified employees, but also provide the fundamental components to facilitate development, diffusion and aggregation of knowledge such as various cooperation platforms and active support from the coordinator. Moreover, in the process of creating knowledge, synergy is generated resulting from the combination of efforts of various people, groups or companies. It seems, therefore, that there is a need to shift the subject of research in the area of open innovation toward the mezzo-level areas of open innovation networks which involve clusters as potential open innovation intermediaries [31].

Clusters could play a significant role in supporting the open approach, especially in companies with relevant constraints, in line with regional or national innovation policy. Moreover, clusters could be vital for reaching the sustainability goals set by all recent political and economic agendas. Clusters seem to create a particularly favorable environment for developing sustainability innovation. According to the previous research, cooperation with external partners (which is typical also for open innovation) is the most important competence allowing companies to implement sustainability innovations $[26,44]$. 


\section{Research Methodology}

\subsection{Methods and Sample}

We report the outcomes of the exploratory qualitative research, which is a section of a larger study aimed at identifying the trajectory of development of relationships in COs [45,46]. The research was based on abduction [47] and the methodology of grounded theory [48]. The study covered cluster organizations including Interizon-The ICT Pomeranian Cluster-which is one of the most mature cluster structures in Poland. As many open innovation practices have been identified in Interizon, it prompted us to conduct a deeper analysis of this cluster organization in the discussed context.

The study was conducted in the first half of 2016. The study sample comprised selected members of Interizon. The application of grounded theory influenced the choice of data collection techniques, which were semistructured in-depth direct interviews. There were, altogether, 11 interviews: with the coordinators (2 interviews), and with representatives of selected cluster members: cluster companies (7) and R\&D institutions (2). The interviewees were the owners or top managers of the companies as well as individuals chosen to represent the organization in the $\mathrm{CO}$. The interview pertained to the cooperation within the $\mathrm{CO}$, the level of commitment in the $\mathrm{CO}$, the development of relationships and trust, cluster benefits, as well as the flows of knowledge and information within the $\mathrm{CO}$; each interview lasted $75 \mathrm{~min}$ on average. Methodological and data triangulations were also used in the study [49], as additional methods applied to the study, including an analysis of the cluster's documents and web resources.

\subsection{Analytic Procedure}

According to the methodology of the grounded theory, the analysis and interpretation of data were carried out using the coding technique. The coding procedure consisted of three stages: open coding, axial coding and selective coding. Open coding involved identification of some common themes. At the stage of axial coding, individual topics were classified with cooperation levels (category 1), open innovation practices (category 2), and the type of information and knowledge (category 3); all these codes were created abductively (Table 1).

Table 1. The axial coding.

\begin{tabular}{|c|c|c|}
\hline No. & Category & Peculiarities \\
\hline 1 & Cooperation levels & $\begin{array}{ll}- & \text { Level I "Integration at the unit level" } \\
- & \text { Level II "Allocation and integration at the process level" } \\
- & \text { Level III "Impact on the environment" } \\
\text { - } & \text { Level IV "Creation and integration at the organizational level" }\end{array}$ \\
\hline 2 & $\begin{array}{l}\text { Open innovation } \\
\text { practices }\end{array}$ & $\begin{array}{ll}- & \text { Participation in meetings } \\
- & \text { Participation in events } \\
- & \text { Participation in task groups } \\
- & \text { Participation in training } \\
- & \text { Lobbing } \\
- & \text { Participation in project groups and consortia } \\
- & \text { Participation in teams focused on the development of } \\
& \text { permanent cooperation }\end{array}$ \\
\hline 3 & $\begin{array}{l}\text { The strength of } \\
\text { relationships }\end{array}$ & $\begin{array}{ll}- & \text { Establishing contact (removing the anonymity barrier) } \\
- & \text { Development of relationships (removing the distrust barrier) } \\
\text { - } & \text { Development of relationships with external partners (outside CO) } \\
\text { - } & \text { Trust development and verification }\end{array}$ \\
\hline
\end{tabular}


Table 1. Cont.

\begin{tabular}{|c|c|c|}
\hline No. & Category & Peculiarities \\
\hline 4 & $\begin{array}{l}\text { Type of information } \\
\text { and knowledge }\end{array}$ & $\begin{array}{ll}- & \text { General information } \\
- & \text { Significant information about the socio-economic environment } \\
- & \text { Detailed information } \\
- & \text { Confidential information } \\
- & \text { New knowledge }\end{array}$ \\
\hline
\end{tabular}

In the selective coding, being the final stage, the categories were grouped to feature different open innovation practices and their benefits in the form of access to information and knowledge observed in our research (Table 2).

Table 2. The selective coding.

\begin{tabular}{|c|c|c|c|}
\hline $\begin{array}{l}\text { Category } 1 . \text { Cooperation } \\
\text { Levels (CLs) }\end{array}$ & $\begin{array}{l}\text { Category 2. Open Innovation } \\
\text { Practices (OIPs) }\end{array}$ & $\begin{array}{l}\text { Category 3. The Strength of } \\
\text { Relationships (SRs) }\end{array}$ & $\begin{array}{l}\text { Category 4. Type of Information } \\
\text { and Knowledge (I\&K) }\end{array}$ \\
\hline $\begin{array}{l}\text { Level I "Integration at the } \\
\text { unit level" }\end{array}$ & $\begin{array}{ll}- & \text { Participation in meetings } \\
\text { - } & \text { Participation in events }\end{array}$ & Establishing contact & General information \\
\hline $\begin{array}{l}\text { Level II "Allocation and } \\
\text { integration at the process } \\
\text { level" }\end{array}$ & $\begin{array}{ll}- & \text { Participation in } \\
& \text { task groups } \\
- & \text { Participation in training }\end{array}$ & $\begin{array}{ll}\text { - } & \text { Development } \\
\text { of relationships }\end{array}$ & Detailed information \\
\hline $\begin{array}{l}\text { Level III "Impact on the } \\
\text { environment" }\end{array}$ & $\begin{array}{l}-\quad \text { Participation in meetings } \\
-\quad \text { Lobbing }\end{array}$ & 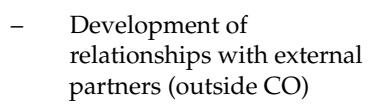 & $\begin{array}{l}\text { - Significant information } \\
\text { about the } \\
\text { socio-economic environment }\end{array}$ \\
\hline $\begin{array}{l}\text { Level IV "Creation and } \\
\text { integration at the } \\
\text { organizational level" }\end{array}$ & $\begin{array}{ll}- & \text { Participation in project } \\
\text { groups and consortia } \\
\text { - } \quad \text { Participation in teams } \\
\text { focused on the } \\
\text { development of } \\
\text { permanent cooperation }\end{array}$ & $\begin{array}{l}\text { Trust development } \\
\text { and verification }\end{array}$ & $\begin{array}{ll}- & \text { Confidential information } \\
- & \text { New knowledge }\end{array}$ \\
\hline
\end{tabular}

\section{Results}

\subsection{General Characteristics of Interizon}

Interizon was established in 2009 as Interizon-The ICT Pomeranian Cluster. It initially brought together 54 participants. Unlike typical COs, which are most often initiated by companies or regional institutions, the function of the initiator, in this case, was performed by one of the Centers of Excellence operating at Gdańsk University of Technology-the WiComm. The university continued to function as the formal administrator of the $\mathrm{CO}$ for several years, successively transferring the coordination competences to the industry. Representatives of the university are still actively involved in the activities of the $\mathrm{CO}$-for example, as members of the Cluster Council or initiators and participants of joint innovative projects.

Currently, Interizon is one of the largest and most dynamically developing COs in Poland. It brings together the members interested in the development of the ICT industry (Information and Communications Technology). It is coordinated by the Interizon Foundation with headquarters in Gdańsk, Poland. The CO currently has 130 members, including representatives of enterprises (mainly SMEs), universities, and business support institutions. The CO works closely with representatives of the local government: metropolitan cities and regional authorities. Employment in the member companies is estimated at over 15,000. The CO includes both small innovative enterprises and large companies with international potential, including the largest companies in the ICT sector in Poland, such as Flextronics. Interizon has the status of a Key National Cluster (KNC) awarded by the Ministry of Economy in cooperation with the Polish Agency for Enterprise Development. The award is given to a cluster of great importance for the country's economy and substantial international 
competitiveness. The cluster ranks high in each edition of the benchmarking study conducted by the Polish Agency for Enterprise Development, setting the benchmark value in many areas [50-52].

\subsection{Practices of Open Innovation in Interizon}

The key finding of the research was that cooperation in COs may have nature and intensity. As a result of the study, four levels of cooperation that may occur simultaneously in a given $\mathrm{CO}$ were distinguished. Level I, defined as "Integration at the unit level", involves building relationships among cluster members, which is necessary for the formation of subsequent levels. At level II, "Allocation and integration at the process level", greater cooperation of cluster entities is visible, which is manifested by the exchange of specific types of resources as well as the integration of some areas of activity (e.g., quality, marketing). Level III, "Impact on the environment", is aimed at achieving collective goals by influencing the environment, including lobbying. The most advanced level IV, "Creation and integration at the organizational level", is about creating shared added value by selected cluster members and integration within the value chain. At each level of cooperation, we identified various open innovation practices, specific to a given level, which is aptly illustrated by Interizon. These open innovation practices emerged in the coding process based on the methodology of grounded theory. They overlap with the main forms of commitment at each of the identified levels [45].

The study showed that the use of these practices by cluster organizations allows access to various types of resources; first of all, relational resources and, consequently, information and knowledge resources. With the transition to the next level of cooperation, the pool of available resources increases-the relationships among cooperating entities strengthen (Table 3) conditioning an increasingly better flow of information and knowledge.

Table 3. Relationships development at various levels of cluster cooperation.

\begin{tabular}{|c|c|c|c|}
\hline (CL) & (OIP) & (SR) & Selected Quotations \\
\hline I & $\begin{array}{ll}- & \text { Participation } \\
\text { in meetings } \\
\text { - } \quad \text { Participation in events }\end{array}$ & Establishing contact & $\begin{array}{l}\text { "The participants start to meet in the cluster, } \\
\text { talk, discuss-relationships develop. Such a } \\
\text { level of trust is very underestimated." (R1) }\end{array}$ \\
\hline II & $\begin{array}{ll}- & \text { Participation in } \\
& \text { task groups } \\
-\quad & \text { Participation } \\
& \text { in training }\end{array}$ & $\begin{array}{l}\text { Development of } \\
\text { relationships }\end{array}$ & $\begin{array}{l}\text { "I was at several such meetings and I found } \\
\text { out that when a person shares, others also } \\
\text { share with him and then the cooperation } \\
\text { evolves different." (R6) }\end{array}$ \\
\hline III & $\begin{array}{ll}\text { - } & \text { Participation } \\
\text { in meetings } \\
\text { - } \quad \text { Lobbing }\end{array}$ & $\begin{array}{l}\text { Development of } \\
\text { relationships with } \\
\text { external partners } \\
\text { (outside CO) }\end{array}$ & $\begin{array}{l}\text { "The cluster is like a bridge: we connect } \\
\text { companies with specific scientists, we get } \\
\text { them to meet, so that various things at the } \\
\text { university are easier to implement." (R2) }\end{array}$ \\
\hline IV & 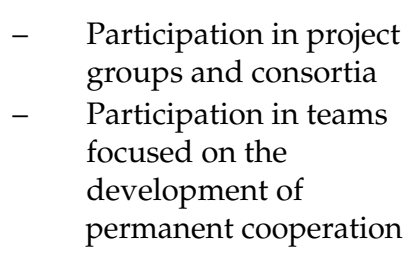 & $\begin{array}{l}\text { Trust development and } \\
\text { verification }\end{array}$ & $\begin{array}{l}\text { "We like each other and we trust each other, } \\
\text { because we have completed a project } \\
\text { together. We have one or two partners, } \\
\text { now the third is being ready with whom we } \\
\text { are able to cooperate. We have already } \\
\text { come to the conclusion that we simply } \\
\text { cannot afford to experiment with that." (R9) }\end{array}$ \\
\hline
\end{tabular}

At level I, the basic forms of cooperation in a $\mathrm{CO}$ are: participation in meetings and participation in events, which turned out to be the most effective open innovation practices (Table 4). In Interizon, several meetings and events are held annually-workshops, conferences, networking meetings, webinars - thematically related to the needs of the ICT industry. Interizon is the main organizer of ICT DAY - an annual conference devoted to the discussion on the development of the ICT industry and the possibility of using information, electronic, and telecommunications technologies in various areas of social and economic life. Each edition of the conference is attended by the representatives of 
the world of business, science, and public administration. As part of ICT DAY, a panel is organized with guided participation of cluster members who share their experiences from cooperation with other conference participants. Such presentations can be treated as part of the demonstration effect in a $\mathrm{CO}$ - the experiences of other companies may become a source of inspiration for other participants and motivate them to be more active within the CO. The active participation of members in meetings and events allows access to a large pool of diverse, but fairly general information that is most easily exchanged during informal meetings which involve face-to-face contacts. On the other hand, the exchange of such general information does not require the establishment of strong relationships between cluster members (Table 3).

Table 4. Open innovation practices at level I of cluster cooperation.

\begin{tabular}{|c|c|c|}
\hline (OIP) & (I\&K) & Selected Quotations \\
\hline $\begin{array}{l}\text { Participation in } \\
\text { meetings }\end{array}$ & \multirow{2}{*}{$\begin{array}{l}\text { General } \\
\text { information }\end{array}$} & $\begin{array}{l}\text { "Information ... I think that's not about newsletters, but off-the-record } \\
\text { discussions. In a place where people can meet and discuss different } \\
\text { subjects and, following multiple meetings, share unofficial knowledge } \\
\text { on different topics-that's where a cluster is helpful for sure. People find } \\
\text { out what is happening on the market, find out about the introduction of } \\
\text { new rules and regulations, or perhaps new requirements-unofficial } \\
\text { news. That's what's not included in the newsletter." (R7) }\end{array}$ \\
\hline $\begin{array}{l}\text { Participation in } \\
\text { events }\end{array}$ & & $\begin{array}{l}\text { "Internal promotion is an important aspect of our cluster. We show } \\
\text { which companies managed to gain specific benefits-we show success } \\
\text { stories. Share specifics that companies want to speak about. } \\
\text { For instance, we have this event called ICT Day, which takes on a } \\
\text { different form each year, but which is organized annually. It was } \\
\text { interesting for companies to see their counterparts publicly speak about } \\
\text { their success stories. Because that's living proof that clusters may be } \\
\text { more beneficial to their members. Companies may learn more about } \\
\text { one another." (R4) }\end{array}$ \\
\hline
\end{tabular}

At level II, two types of activity turned out to be crucial in terms of open innovation, the first of which was participation in task groups (Table 5). In Interizon, task groups are created primarily to integrate participants around common problems and goals. Task groups organize their own meetings, independent of other meetings within the CO. Research shows that the more advanced the form of cooperation within a group, the greater the frequency of such meetings, the higher the attendance, and the smaller the size of the group. As the example of Interizon shows, participation in task groups brings further benefits to participants, in addition to those directly related to the results achieved by the group. There is a much greater flow of information in task groups than in the CO forum during general meetings organized for all cluster members. The information exchanged by group participants is more personalized and tailored to the needs of the participants, which, compared to level I, brings greater benefits to the members involved. It is facilitated by the greater openness of the participants who can strengthen their bonds through more frequent and regular group meetings. In task groups, there is a specific community of goals, and thus cooperation to achieve common benefits, which further strengthens the ties between participants (Table 3).

The second open innovation practice identified at level II was participation in training (Table 5). An example that illustrates the processes of knowledge sharing in Interizon is a Foundation established within the Interizon structure dealing with staff training for the needs of cluster companies. The foundation acts as a broker-it examines and analyzes the needs of companies in the field of increasing employee competences, and then seeks out trainers who could fill the identified gaps, thanks to which the subject of training is closely matched to customer requirements. Identification of entrepreneurs' needs is carried out by the Foundation, most often based on direct contact with representatives of companies, which ensures a two-way, interactive exchange of information. As a result, the information provided is more accurate and can be additionally detailed. Personal contact 
authenticates the obtained information and creates an opportunity to get to know each other, which breaks the anonymity barrier, making it easier for the parties to establish cooperation. The Foundation is also involved in the organization of internal training within Interizon, with the active participation of cluster members (acting as trainers). There is mutual learning in Interizon-the members of companies exchange knowledge by providing one another with training services in the subject in which they feel competent. The respondents emphasize that this type of activity is based on a high level of openness and reciprocity; therefore, the information exchange occurs only among selected members, between whom trust has been built (Table 3). Both described practices (task groups and training) foster the development of ties among selected participants, and thereby facilitate the exchange of various types of resources (including material, financial and human resources), but, above all, they are used to exchange information, which, unlike information on level I, is more detailed and tailored to the recipients' profiles.

Table 5. Open innovation practices at level II of cluster cooperation.

\begin{tabular}{|c|c|c|}
\hline (OIP) & $(I \& K)$ & Selected Quotations \\
\hline $\begin{array}{l}\text { Participation in } \\
\text { task groups }\end{array}$ & \multirow{2}{*}{$\begin{array}{l}\text { Detailed } \\
\text { information }\end{array}$} & $\begin{array}{l}\text { "This industry is so extensive, knowledge is so vast that it cannot be } \\
\text { fully understood. Therefore, it is imperative to choose the appropriate } \\
\text { thematic threads and someone has to do it for someone to cede. It is } \\
\text { best for companies that hope to develop their business in specific } \\
\text { directions and will dig." (R10) }\end{array}$ \\
\hline $\begin{array}{l}\text { Participation in } \\
\text { training }\end{array}$ & & $\begin{array}{l}\text { "The exchange of resources-is very, very much present within human } \\
\text { capital. We have a foundation which is tasked with personnel training, } \\
\text { where this phenomenon is present to a large degree. Mutual teaching } \\
\text { about project management, mutual teaching of programming languages } \\
\text { [... ] training sessions, mutual workshops, we had numerous such } \\
\text { sessions where people would teach one another." (R1) }\end{array}$ \\
\hline
\end{tabular}

The research shows that, at level III, lobbying and the related participation in meetings with entities from outside the $\mathrm{CO}$ is the most important open innovation practice (Table 6). Interizon members engage in various forms of cooperation with other companies with a view to creating more favorable legal and administrative conditions for running a business, as well as to adjusting the educational profile in the region to the needs of companies. An example of such activity is the commitment to define the Smart Specialization of the Pomeranian region and establish partnerships for RSS. The ICT cluster industry is in line with the Smart Specialization of the Pomeranian region within which it operates. Interizon was the leader in organizing the process of entrepreneurial discovery of specialization in this area. Currently, it is the leader of the Pomeranian Smart Specialization called "Interactive technologies in an information-saturated environment" (PSS2). The goal of this specialization is to build and strengthen international competitiveness and accelerate the growth rate of enterprises in the ICT sector in the Pomeranian Voivodeship. As a coordinator, the Interizon Foundation organizes various networking meetings and workshops addressed to cluster members and other involved entities. The cluster cooperates with the local government administration also in other important regional initiatives-cluster members take part in consultations on large regional projects and strategic development programs for the region. The above activities undertaken by Interizon lead to the gradual activation of new entities operating in the ICT industry in Pomerania, which in turn enables the further development of cooperation between key regional entities. This, in turn, leads to the development of relationships with external partners operating outside the $\mathrm{CO}$ (Table 3). Thanks to these relationships, cluster participants also have the opportunity to use the services of experts with business and academic backgrounds cooperating with the cluster. Interizon closely cooperates with specialists and scientists from the ICT industry and advisors in the field of law, new technologies, etc. The cluster conducts international activities, including contacts with over a dozen European and non-European ICT clusters. This way, Interizon members gain advantage in obtaining significant 
information about the environment that they can use in their business activities. It also works the other way around-Interizon as an organization associating entities bound by a common goal can also influence the environment by sharing the knowledge and experience of its members.

Table 6. Open innovation practices at level III of cluster cooperation.

\begin{tabular}{|c|c|c|}
\hline (OIP) & (I\&K) & Selected Quotations \\
\hline Lobbing & \multirow{2}{*}{$\begin{array}{l}\text { Significant } \\
\text { information } \\
\text { about the } \\
\text { socio-economic } \\
\text { environment }\end{array}$} & $\begin{array}{l}\text { "We have contact with the local administration and the central } \\
\text { authorities, we participate in different assemblies, we have our } \\
\text { representative in the committee monitoring the Ombudsman } \\
\text { and in the National Centre for Research and Development. } \\
\text { Whenever there is a committee in the Sejm which deals with } \\
\text { clustering, one of our members participates in its meetings." (R2) }\end{array}$ \\
\hline $\begin{array}{l}\text { Participation in } \\
\text { meetings (with entities } \\
\text { from outside CO) }\end{array}$ & & $\begin{array}{l}\text { "The involved cluster members first learn about the created, } \\
\text { emerging consortia for projects from the European Commission, } \\
\text { from large grants." (R1) }\end{array}$ \\
\hline
\end{tabular}

As the research shows, at the highest level of cooperation (level IV), the main open innovation practices are participation in project groups and consortia as well as participation in teams focused on the development of permanent cooperation (value chain cooperation and common products) (Table 7). In the case of Interizon, the key is the first of these practices-cooperation in the implementation of joint projects which results from the specific nature of the ICT industry. As part of the $\mathrm{CO}$, companies receive support in searching for business partners for jointly implemented innovative projects. They also receive support in creating project consortia on a large scale, including the international scale. These projects are innovative research and development projects, mostly cofinanced from EU funds (Horizon 2020) and/or national funds allocated to research and innovation (National Center for Research and Development). There is a high level of commitment and cofinancing by business partners-cluster members, in all innovative projects. The budgets of projects (of the Polish part of the consortia) reach several million euros. In most cases, companies participating in large international projects were not involved in this type of activity before joining the cluster. In particular, the $\mathrm{CO}$ facilitates the establishing of partnerships through support in finding partners, content-related consultations, project management support, model contracts, operating procedures, solutions in the field of intellectual property, etc. In some cases, the cluster initiative takes on the role of the project coordinator, but in most cases, the project leaders (or the leaders of Polish parts of the international consortia) are SME members of the cluster. In project groups created at this level of cooperation, the trust created between partners in earlier acts of cooperation poses a certain barrier to access (Table 3). By collaborating in project groups, participants gain access to confidential information, reserved only for the most trusted members, and access to new knowledge which is often created as part of project collaboration.

A good example of cooperation at level IV is the participation of some Interizon members in the Adaptive Cooperative Control in Urban (sub) Systems project. The project officially started on 1 June 2013 and lasted until 31 January 2016. The specific nature of the ACCUS (Adaptive Cooperative Control of Urban Subsystems) project sheds new light on how to ensure the implementation of the idea of sustainable development. The essence of the project was to create a platform for the integration of various city systems: intelligent transport systems, city light systems, and energy management systems. Each of these systems was designed in accordance with specific assumptions-the common idea behind their operation was to optimize the processes that these systems were to manage. Optimizing the operation of spheres with even a small scope of impact is a small step toward sustainable development, while the integration of these efforts, and thus a kind of "optimization of minor optimizations", is a big leap in this direction. The project was attended by those Interizon entities that showed great involvement in cluster matters and had adequate experience and a potential to carry out the tasks entrusted to them. Successful activities not only strengthened the trust between Interizon members 
but also started the process of building trust between Interizon entities and other entities participating in the project (e.g., from Spain, Italy, and The Netherlands).

Table 7. Open innovation practices at level IV of cluster cooperation.

\begin{tabular}{lll}
\hline \multicolumn{1}{c}{ (OIP) } & \multicolumn{1}{c}{ (I\&K) } & \multicolumn{1}{c}{ Selected Quotations } \\
\hline $\begin{array}{l}\text { Participation in project } \\
\text { groups and consortia }\end{array}$ & $\begin{array}{l}\text { Confidential } \\
\text { information }\end{array}$ & $\begin{array}{l}\text { "Knowledge arises in projects. Some of the documents are open } \\
\text { to everyone, part only for people who have carried out these } \\
\text { projects." (R5) }\end{array}$ \\
$\begin{array}{l}\text { Participation in teams } \\
\text { "Wecused on the } \\
\text { development of } \\
\text { permanent cooperation }\end{array}$ & $\begin{array}{l}\text { New } \\
\text { knowledge }\end{array}$ & $\begin{array}{l}\text { completed one project together. We have one, two partners, now } \\
\text { the third one is joining, with whom we are able to cooperate. } \\
\text { (...) Thanks to that we are able to trust each other, exchange } \\
\text { information, talk about new possibilities". (R9) }\end{array}$ \\
\hline
\end{tabular}

\section{Discussion}

At the beginning of the discussion, it should be emphasized that in the literature there are no publications that would be characterized by a holistic approach to cooperation in cluster organizations, such as the proposed concept of trajectory for the development of cooperative relationships in cluster organizations [45,46]. Most of the publications refer to cooperation development in clusters (understood in economic or geographic terms), not in cluster organizations. An example of this are typologies of clusters based on an evolutionary approach [53] as well as those based on the life cycle-e.g., [54-57]. They do not match the specific nature of COs, which have separate life cycles, only partially overlapping with the life cycle of clusters. The model of development of cluster initiatives was presented by Sölvell, Lindqvist, and Ketels $[58,59]$. However, it does not reflect the development of cooperative relationships in such organizations.

The results of the research clearly indicate that Interizon has a tendency to retain the most valuable information resources for trusted partners who are deeply involved in the cooperation process. Hence, access to confidential information and knowledge appeared only at the level of project cooperation involving the strongest, most determined and proven partners. Detailed information could be accessed through task groups-it can be assumed that the scope of this information coincided with the area of the task to be performed by a given group of entities. Relevant information of general significance was obtained primarily from outside of the $\mathrm{CO}$ or attempts were made to generate it through the lobbying process. In turn, general information was available to all cluster members during meetings and special events held there. Therefore, it is clearly visible that the value of information, its uniqueness and, at the same time, adaptation to the needs of a specific group of entities increased with the level of cluster cooperation at which Interizon members operated. It was also associated with the gradual development of relationships, first within the entire cluster organization, and then in increasingly smaller groups, in which ties based on trust were gradually developed (Figure 1).

The results of the study can also be viewed from the perspective of open innovation and its three main directions: inbound, outbound, and coupled. At levels II and IV, the members of Interizon were balancing on the verge of equilibrium between what they took "from the outside" and what came "from the inside" - the information flows here were bilateral, coupled, and driving the process of information exchange characteristic for level II and the process of generating new knowledge specific to level IV. The inbound direction occurred on level I-at this level Interizon obtained a wide range of information "from the outside". Level III, in turn, is obviously outbound-Interizon and its constituent entities have gone beyond their limits in order to exert a specific influence on their immediate and distant surroundings.

The results seem to clearly indicate that diversity, which is a feature that distinguishes cluster organizations from other types of organizations, is an element that deserves special emphasis. However, it should be sustainable diversity, in which the difference in skills and knowledge represented by the 
individual entities involved in cooperation is an asset and not a threat. Companies in dynamic settings need to constantly reach out to numerous partners and even acknowledge a certain level of redundancy in their peripheral contacts, in order to manage their developing but hugely uncertain knowledge shortages [60]. Strict selection of component entities might even decrease the potential of the cluster organization. However, for diversity to be sustainable in the long term, it has to be well-managed to reduce the probability of conflict and to take advantage of the benefits of open innovation. It is the features of companies and their inherent heterogenity that create the environment that ultimately enhances cluster firm performance [61].

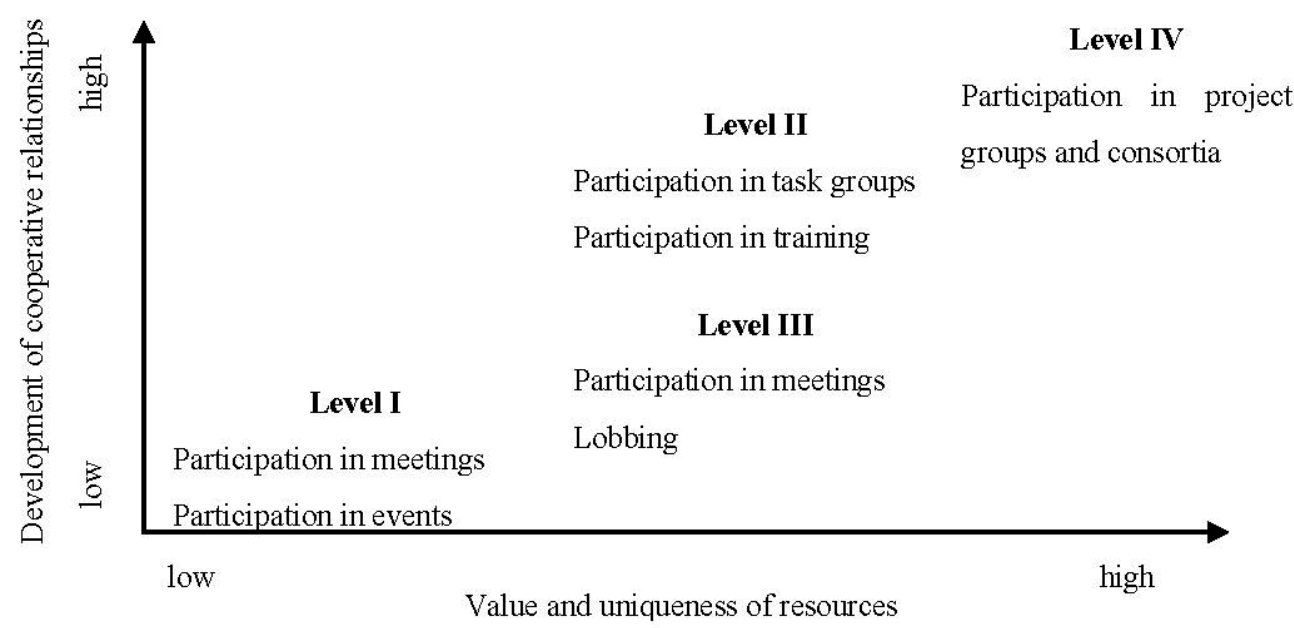

Figure 1. Open innovation practices, relationships and access to resources in cluster organization.

With regard to the literature, the results of the study confirm that clusters could be viewed as innovation ecosystems, whose development depends on the coordination of innovative activities of various partners [43], and whose different levels of open innovation practices can be a source of formal and informal know-how for members and that they can strengthen the ties of companies and other partners in terms of potential open innovation projects [62]. Furthermore, with regard to the activities of clusters in terms of sustainability, it seems that the intricacy of sustainability innovations and limited experience of organizations, especially SMEs, in terms of their development and bringing them to the market, calls for increased competence, formation of new alliances, and effective intermediation [4]. This suggests that, within clusters, open innovation and sustainability innovation goals can be achieved simultaneously.

\section{Conclusions}

The study conducted in Interizon explores how cluster organizations could operate as open innovation intermediaries. The use of grounded theory to collect and analyze data made it possible to select categories important from the point of view of the development of cooperation in COs. This takes on greater significance in the face of the identified research gap. There are no publications in the literature that have simultaneously dealt with the three issues discussed in the study: cooperation, open innovation, and sustainability, especially in a cluster organization, which is a fairly recent concept, growing out of the Porter cluster concept.

Our findings add to the state-of-the-art knowledge on the link between the concepts of cluster and open innovation. They illustrate open innovation practices used by cluster organizations and the role of COs in providing information and knowledge as a result of applying those practices. The forms of cluster cooperation, identified in this study by using the procedures developed within the grounded theory methodology, constitute the basic, albeit not exhaustive, set of open innovation practices. Each of these forms is conducive to the development of open innovation, contributing to the gaining of access to a new pool of information and knowledge. It is worth emphasizing that by combining 
open innovations with cluster organizations, a synergy effect for sustainable development could be achieved. A cluster, due to its specificity, is an environment enabling cooperation, including the joint open generation of new solutions, quintessential for sustainability-led innovation.

As it is noted, regardless of the level of cooperation or the nature of the innovations outlined in each of them, it is important that there is proximity between cluster entities. This is of key importance for the success of each of the acts of cooperation that is undertaken in Interizon. Initially, the greatest role is played by geographical proximity which allows for a natural reduction in barriers between cluster entities-a common location, similar cultural foundations, and shared advantages and disadvantages of the region are all features that played a significant role for cluster entities at levels I and II of cooperation. At level II, the foundations of social proximity have already appeared, which, by creating the conviction of a certain commonality of fate among some cluster entities, pushed them to greater involvement and introduced them to level III. However, social proximity was of the greatest importance at the highest level of cooperation-level IV. Open innovation practices assigned to this level were developed only by trusted entities with appropriate potential to perform specific tasks, the usefulness of which has most often already been proved valuable in previous cooperation projects. Nevertheless, geographical proximity-although gradually declining in importance at each of the distinguished levels of cooperation-retained, until the end, the status of a facilitator for basically all activities undertaken within the $\mathrm{CO}$.

It is widely accepted that innovations generated in networks with a greater organizational diversity have greater economic capacity [63]. In this paper, the notion of sustainable diversity is proposed. The advantage of sustainable diversity is that it gives significance to different but complementary objectives of cluster partners. This can be an advantage for the practitioner perspective, where cluster managers must deal with many different stakeholders that are confronted by diverse references of constraint and opportunities. For example, Smith and Brown [64] propose a system thinking approach to understand interfirm cooperation and network development and Burt [65] underlines the importance of structural holes and transferring vital information in between different groups of stakeholders-and, consequently, coming up with the most innovative ideas. Generally, a higher diversity in the category of collaboration stakeholders sets up greater possibilities for common learning, helps acquire various capabilities, induces a better mixture of invention and originality, and provides more efficient solutions to obstacles. On the other hand, more diverse networks might come across problems arising from dissimilarities in organizational capacities between stakeholders. Moreover, managerial issues might appear when different partners involved in cooperation partnerships seek to adjust their various goals and perspectives [63]. Additionally, companies might be cautious of involving themselves in cooperation projects for competitive reasons. Furthermore, large firms might be not that inclined to share their technical and market expertise with small competitors and more willing to cooperate with other larger companies to expand the potential incorporation of spillovers. Although the net result of a higher diversity in a project appears to be beneficial, it is, therefore, relevant to emphasize that it takes a specific type of network management that can enhance the sustainable diversity in a cluster and ensure effective performance [61].

The findings corroborate the results of many studies indicating that both companies' in-house competence, and the level of embeddedness in a regional network, affect their efficiency $[66,67]$. The authors evidence how clusters develop from competition through cooperation into deeper collaboration. Therefore, the empirical findings can provide practical implications for cluster coordinators. They can implement a variety of open innovation practices, contributing to the flow of knowledge and information within a CO, taking advantage of two important pillars of a cluster organization: localization and networked relationships.

The policy implications of the findings include the advantages of clusters in adapting open innovation which might be prevailing in the context of sustainability innovation. In the light of the results of this study, the focus of the policy should be placed on learning in a flexible framework that evolves to reflect changes in cluster environment and structure. The type of governance of cluster 
organizations influences the innovation performance of cluster member firms [68]. Furthermore, the way in which a cluster organization is managed is expected to influence effects visible at the level of cluster organizations, which, in turn, has repercussions at the level of the local or regional economy.

Our research has some limitations, resulting from the specific nature of the qualitative research and a small sample. It should be treated as an introductory voice in a broader discussion of cluster organizations as open innovation intermediaries. For a better understanding of open innovation collaboration within COs, more in-depth and representative research (both qualitative and quantitative) on a larger sample would be required. It seems important that the most effective open innovation practices be determined and that the relations between their application and the strength of the relationships, and the amount of information and knowledge resources available in the $\mathrm{CO}$, be examined, which may translate into a greater innovation potential of cluster members.

Author Contributions: The co-authors worked together towards the completion of this article. A.M.L. was in charge of conceptualization, methodology, data collection and analyzing, final results, discussion, and conclusions. M.M. was in charge of theoretical background, final results, discussion, and conclusions. A.L. contributed to revising final results, discussion, and conclusions. All authors have read and agreed to the published version of the manuscript.

Funding: This research received no external funding.

Conflicts of Interest: The authors declare no conflict of interest.

\section{References}

1. Dalby, S. Climate Change, Security and Sustainability. In Achieving the Sustainable Development Goals: Global Governance Challenges; Dalby, S., Horton, S., Mahon, R., Thomaz, D., Eds.; Routledge: London, UK; New York, NY, USA, 2019; pp. 117-131.

2. European Commission. Communication from the Commission to the European Parliament, the Council, the European Economic and Social Committee and the Committee of the Regions, a New ERA for Research and Innovation; COM/628 Final; Office for Official Publications of the European Communities: Brussels, Belgium, 2020.

3. Kern, F.; Rogge, K.S.; Howlett, M. Policy mixes for sustainability transitions: New approaches and insights through bridging innovation and policy studies. Res. Policy 2019, 48, 103832. [CrossRef]

4. Rauter, R.; Globocnik, D.; Perl-Vorbach, E.; Baumgartner, R.J. Open innovation and its effects on economic and sustainability innovation performance. J. Innov. Knowl. 2019, 4, 226-233. [CrossRef]

5. Chakrabarti, R.; Henneberg, S.C.; Ivens, B.S. Open sustainability: Conceptualization and considerations. Ind. Mark. Manag. 2020, 89, 528-534. [CrossRef]

6. Bogers, M.; Zobel, A.-K.; Afuah, A.; Almirall, E.; Brunswicker, S.; Dahlander, L.; Frederiksen, L.; Gawer, A.; Gruber, M.; Haefliger, S.; et al. The open innovation research landscape: Established perspectives and emerging themes across different levels of analysis. Ind. Innov. 2017, 24, 8-40. [CrossRef]

7. Gao, H.; Ding, X.-H.; Wu, S. Exploring the domain of open innovation: Bibliometric and content analyses. J. Clean. Prod. 2020, 275, 122580. [CrossRef]

8. Leckel, A.; Veilleux, S.; Dana, L.P. Local Open Innovation: A means for public policy to increase collaboration for innovation in SMEs. Technol. Forecast. Soc. Chang. 2020, 153, 119891. [CrossRef]

9. Natalicchio, A.; Ardito, L.; Savino, T.; Albino, V. Managing knowledge assets for open innovation: A systematic literature review. J. Knowl. Manag. 2017, 21, 1362-1383. [CrossRef]

10. Nestle, V.; Täube, F.A.; Heidenreich, S.; Bogers, M. Establishing open innovation culture in cluster initiatives: The role of trust and information asymmetry. Technol. Forecast. Soc. Chang. 2019, 146, 563-572. [CrossRef]

11. Mignon, S.; Ayerbe, C.; Dubouloz, S.; Robert, M.; West, J. Managerial Innovation and Management of Open Innovation. J. Innov. Econ. Manag. 2020, 32, 3-12. [CrossRef]

12. West, J.; Salter, A.; Vanhaverbeke, W.; Chesbrough, H. Open innovation: The next decade. Res. Policy 2014, 43, 805-811. [CrossRef]

13. Ovuakporie, O.D.; Pillai, K.G.; Wang, C.; Wei, Y. Differential moderating effects of strategic and operational reconfiguration on the relationship between open innovation practices and innovation performance. Res. Policy 2021, 50, 104146. [CrossRef] 
14. Mahdad, M.; De Marco, C.E.; Piccaluga, A.; Di Minin, A. Harnessing adaptive capacity to close the pandora's box of open innovation. Ind. Innov. 2020, 27, 264-284. [CrossRef]

15. Dahlander, L.; Gann, D.M. How open is innovation? Res. Policy 2010, 39, 699-709. [CrossRef]

16. Rahman, H.; Ramos, I. Open Innovation in SMEs: From Closed Boundaries to Networked Paradigm. Issues Inf. Sci. Inf. Technol. 2010, 7, 471-487. [CrossRef]

17. European Commission. Open Innovation 2.0 Yearbook 2017-2018. 2018. Available online: https://op.europa. eu/en/publication-detail/-/publication/10defd18-d291-11e8-9424-01aa75ed71a1 (accessed on 6 August 2020).

18. McPhillips, M. Innovation by proxy-clusters as ecosystems facilitating open innovation. J. Entrep. Manag. Innov. 2020, 16, 101-128. [CrossRef]

19. Porter, M.E. On Competition; Harvard Business School Publishing: Boston, MA, USA, 2008.

20. Carayannis, E.G.; Campbell, D.F.J. "Mode 3" and "Quadruple Helix": Toward a 21st century fractal innovation ecosystem. Int. J. Technol. Manag. 2009, 46, 201-234. [CrossRef]

21. Lämmer-Gamp, T.; zu Köcker, G.M.; Nerger, M. Cluster Collaboration and Business Support Tools to Facilitate Entrepreneurship, Cross-Sectoral Collaboration and Growth. 2014. Available online: https: //ec.europa.eu/docsroom/documents/9972 (accessed on 6 August 2020).

22. Shearmur, R.; Doloreux, D. How open innovation processes vary between urban and remote environments: Slow innovators, market-sourced information and frequency of interaction. Entrep. Reg. Dev. 2016, 28, 337-357. [CrossRef]

23. Delgado, M. The co-location of innovation and production in clusters. Ind. Innov. 2020, 27, 842-870. [CrossRef]

24. Gotz, M. Cluster role in industry 4.0-A pilot study from Germany. Compet. Rev. Int. Bus. J. 2020. (Issue ahead-of-print). [CrossRef]

25. De Marco, C.E.; Martelli, I.; Di Minin, A. European SMEs' engagement in open innovation When the important thing is to win and not just to participate, what should innovation policy do? Technol. Forecast. Soc. Chang. 2020, 152, 119843. [CrossRef]

26. Arnold, M. Fostering sustainability by linking co-creation and relationship management concepts. J. Clean. Prod. 2017, 140, 179-188. [CrossRef]

27. Chesbrough, H.; Bogers, M. Explicating Open Innovation. In New Frontiers in Open Innovation; University Press: Oxford, UK, 2014; pp. 3-28.

28. Lyu, Y.; He, B.; Zhu, Y.; Li, L. Network embeddedness and inbound open innovation practice: The moderating role of technology cluster. Technol. Forecast. Soc. Chang. 2019, 144, 12-24. [CrossRef]

29. Knockaert, M.; Spithoven, A.; Clarysse, B. The impact of technology intermediaries on firm cognitive capacity additionality. Technol. Forecast. Soc. Chang. 2014, 81, 376-387. [CrossRef]

30. Howells, J. Intermediation and the role of intermediaries in innovation. Res. Policy 2006, 35, 715-728. [CrossRef]

31. De Silva, M.; Howells, J.; Meyer, M. Innovation intermediaries and collaboration: Knowledge-based practices and internal value creation. Res. Policy 2018, 47, 70-87. [CrossRef]

32. Radziwon, A.; Bogers, M. Open innovation in SMEs: Exploring inter-organizational relationships in an ecosystem. Technol. Forecast. Soc. Chang. 2019, 146, 573-587. [CrossRef]

33. Edler, J.; Yeow, J. Connecting demand and supply: The role of intermediation in public procurement of innovation. Res. Policy 2016, 45, 414-426. [CrossRef]

34. Smedlund, A. The roles of intermediaries in a regional knowledge system. J. Intellect. Cap. 2006, 7, $204-220$. [CrossRef]

35. Randhawa, K.; Wilden, R.; Gudergan, S. Open Service Innovation: The Role of Intermediary Capabilities. J. Prod. Innov. Manag. 2018, 35, 808-838. [CrossRef]

36. Agogué, M.; Berthet, E.; Fredberg, T.; Le Masson, P.; Segrestin, B.; Stoetzel, M.; Wiener, M.; Yström, A. Explicating the role of innovation intermediaries in the "unknown": A contingency approach. J. Strategy Manag. 2017, 10, 19-39. [CrossRef]

37. Turkina, E.; Oreshkin, B.; Kali, R. Regional innovation clusters and firm innovation performance: An interactionist approach. Reg. Stud. 2019, 53, 1193-1206. [CrossRef]

38. Jankowska, B.; Götz, M. Internationalization intensity of clusters and their impact on firm internationalization: The case of Poland. Eur. Plan. Stud. 2017, 25, 958-977. [CrossRef]

39. Velt, H.; Torkkeli, L.; Laine, I. Entrepreneurial Ecosystem Research: Bibliometric Mapping of the Domain. J. Bus. Ecosyst. 2020, 1, 43-83. [CrossRef] 
40. Autio, E.; Thomas, L. Innovation ecosystems. In The Oxford Handbook of Innovation Management; OUP: Oxford, UK, 2014; pp. 204-288.

41. Asplund, F.; Björk, J.; Magnusson, M.; Patrick, A.J. The genesis of public-private innovation ecosystems: Bias and challenges. Technol. Forecast. Soc. Chang. 2021, 162, 120378. [CrossRef]

42. Xu, Z.; Maas, G. Innovation and Entrepreneurial Ecosystems as Important Building Blocks. In Transformational Entrepreneurship Practices; Springer International Publishing: New York, NY, USA, 2019; pp. 15-32.

43. Adner, R.; Kapoor, R. Value creation in innovation ecosystems: How the structure of technological interdependence affects firm performance in new technology generations. Strateg. Manag. J. 2010, 31, 306-333. [CrossRef]

44. Lee, K.-H.; Kim, J.-W. Integrating Suppliers into Green Product Innovation Development: An Empirical Case Study in the Semiconductor Industry. Bus. Strateg. Environ. 2011, 20, 527-538. [CrossRef]

45. Lis, A.M. Wspótpraca w Inicjatywach Klastrowych. Rola Bliskości w Rozwoju Powiazań Kooperacyjnych [Cooperation in Cluster Initiatives: The Role of Proximity in the Development of Cooperative Relationships]; Wydawnictwo Politechniki Gdanskiej: Gdansk, Poland, 2018.

46. Lis, A.M. The significance of proximity in cluster initiatives. Compet. Rev. Int. Bus. J. 2019, 29, 287-310.

47. Peirce, C.S. Collected Works; Harvard University Press: Cambridge, MA, USA, 1958.

48. Glaser, B.G.; Strauss, A.L. The Discovery of Grounded Theory. Strategies for Qualitative Research; Aldine de Gruyter: Chicago, IL, USA, 1967; Available online: http://www.sxf.uevora.pt/wp-content/uploads/2013/03/ Glaser_1967.pdf (accessed on 16 December 2020).

49. Maxwell, J.A. Qualitative Research Design: An Interactive Approach; Sage Publications: Thousand Oaks, CA, USA, 2005.

50. Benchmarking klastrów w Polsce-2010. Raport z badania [Cluster Benchmarking in Poland-2010. Research Report]. Available online: https://www.parp.gov.pl/images/sites/ClusterFY/Benchmarking_klastrow_w_ Polsce_-_2010.pdf (accessed on 16 December 2020).

51. Hołub-Iwan, J. (Ed.) Benchmarking klastrów w Polsce_Edycja 2012; Raport z Badania; PARP: Warszawa, Poland, 2012.

52. Plawgo, B. Benchmarking klastrów w Polsce-Edycja 2014; Raport z badania; PARP: Warszawa, Poland, 2014.

53. Van Dijk, M.P.V.; Sverrisson, Á. Enterprise clusters in developing countries: Mechanisms of transition and stagnation. Entrep. Reg. Dev. 2003, 15, 183-206. [CrossRef]

54. Pouder, R.; John, C.H.S. Hot spots and blind spots: Geographical clusters of firms and innovation. Acad. Manag. Rev. 1996, 21, 1192-1225. [CrossRef]

55. Isaksen, A.; Hauge, E. Regional clusters in Europe. Obs. Eur. Smes 2002, 3, 5-55.

56. Rosenfeld, S.A. Creating Smart Systems: A Guide to Cluster Strategies in Less Favoured Regions; Regional Technology Strategies: Carrboro, NC, USA, 2002.

57. Sonderegger, P.; Täube, F. Cluster life cycle and diaspora effects: Evidence from the Indian IT cluster in Bangalore. J. Int. Manag. 2010, 16, 383-397. [CrossRef]

58. Sölvell, Ö.; Lindqvist, G.; Ketels, C. The Cluster Initiative Greenbook; Ivory Tower: Stockholm, Sweden, 2003.

59. Lindqvist, G.; Ketels, C.; Sölvell, Ö. The Cluster Initiative Greenbook 2.0; Ivory Tower: Stockholm, Sweden, 2013.

60. OECD. Promoting Entrepreneurship and Innovative SMEs in a Global Economy. 2004. Available online: https://www.oecd.org/cfe/smes/31919590.pdf (accessed on 6 June 2020).

61. Giuliani, E. Networks and heterogeneous performance of cluster firms. In Applied Evolutionary Economics and Economic Geography; Edward Elgar Publishing: Cheltenham, UK, 2007; pp. 161-179.

62. Radziwon, A.; Bogers, M.; Bilberg, A. Managing Open Innovation across SMEs: The Case of a Regional Ecosystem. Acad. Manag. Proc. 2014, 2014, 11740. [CrossRef]

63. Nepelski, D.; Van Roy, V.; Pesole, A. The organisational and geographic diversity and innovation potential of EU-funded research networks. J. Technol. Transf. 2019, 44, 359-380. [CrossRef]

64. Smith, M.; Brown, R. Exploratory Techniques for Examining Cluster Dynamics: A Systems Thinking Approach. Local Econ. 2009, 24, 283-298. [CrossRef]

65. Burt, R.S. Structural Holes Versus Network Closure as Social Capital. In Social Capital: Theory and Research; Lin, N., Cook, K., Burt, R.S., Eds.; Transaction Publishers: New Brunswick, NJ, USA, 2008; pp. 31-56.

66. Duysters, G.; Lokshin, B. Determinants of alliance portfolio complexity and its effect on innovative performance of companies. J. Prod. Innov. Manag. 2011, 28, 570-585. [CrossRef]

67. Laursen, K.; Salter, A. Open for innovation: The role of openness in explaining innovation performance among UK manufacturing firms. Strateg. Manag. J. 2006, 27, 131-150. [CrossRef] 
68. Berthinier-Poncet, A.; Cluster Governance and Institutional Dynamics. A Comparative Analysis of French Regional Clusters of Innovation. Available online: https://emnet.univie.ac.at/uploads/media/Berthinier_ Poncet.pdf (accessed on 16 December 2020).

Publisher's Note: MDPI stays neutral with regard to jurisdictional claims in published maps and institutional affiliations.

(C) 2020 by the authors. Licensee MDPI, Basel, Switzerland. This article is an open access article distributed under the terms and conditions of the Creative Commons Attribution (CC BY) license (http://creativecommons.org/licenses/by/4.0/). 